\title{
Training And Development In SMEs: South Africa's Key To Survival And Success?
}

\author{
Claudette Rabie, University of South Africa, South Africa \\ Michael C. Cant, University of South Africa, South Africa
}

Johannes A. Wiid, University of South Africa, South Africa

\begin{abstract}
In today's competitive business environment, the capabilities and skills of employees are fundamental requirements for continuous productivity, innovation and success in small and medium enterprises (SMEs). However, the situation of SMEs with regards to training and development is characterised by a paradox and are considered to be crucial elements of competitiveness and success against the backdrop of globalisation. Previous studies have found that constant training and development initiatives are less likely to be available to employees working in SMEs than to those in larger organisations. The study therefore aims to determine the perception of entrepreneurs or SME owners towards the importance of training and development in their business. A self-administered questionnaire was sent to SME owners and a total of 60 usable responses were received. The study showed, amongst others, that a lack of resources is stronger than the influence of business management and external assistance.
\end{abstract}

Keywords: Training and Development; Skills; SMEs; Entrepreneurs; South Africa

\section{INTRODUCTION}

Q mall and Medium-sized Enterprises (SMEs) play a pivotal role in the economies of all countries worldwide and are major contributors to income generation, outputs and the level of employment in a country. With approximately $68 \%$ of the South African population being employed by SME businesses (Adcorp, 2012:1), SMEs have long been acknowledged as fundamental contributors to the economic health of countries on an international spectrum. Rob Davies (Minister of Trade and Industry) noted that SMEs has an exceptionally high failure rate, as a staggering $70 \%$ of the country's SMEs fail in their first year - putting South Africa on the map as the country with the highest failure rate in the world (SBP Alert, 2014:2). Apart from this, the latest universal financial crises experienced on all continents has also left SMEs in a particular harsh environment, with a reduction in demand for products and services and shrinkage in the amount of loans by banks and other financial institutions (Edinburgh Group, 2013:3). The high failure rate and financial and economic turmoil has led to SMEs being faced with numerous challenges and the competition among SMEs exacerbated even further (UEAPME, n.d.:1). Inadequate management skills, expertise in key function areas and the lack of adequate financial understanding, as denoted by Cant and Wiid (2013:709), are the major causes of SME failing in South Africa. Hence, the battle for aptitude and proficiencies became a reality for SMEs, which led to the increased awareness for the need for training and development in SMEs (UEAPME, n.d.:1).

Kulkarni (2013:136) explains training to be the nerve that bares the necessity for the eloquent and impeccable functioning of work, which assists in boosting the excellence of work, the lives of employees as well as organisational development. Ongori and Nzonzo (2011:187), further states that the training and development of employees is crucial in organisations in this era of competition, especially in SMEs, due to the fact that organisations need to service, cultivate and progress in their markets. Today training is one of the most important factors in the business world, as training assists in the development of competences and efficiency of both the employee and the organisation. The performance and productivity of employees rely on many factors, the most important being employee training and development (Laing, 2009:11). Loan-Clarke, Boocook, Smith and Wittaker (1999:296) noted that the more affluent businesses provide their employees with further training as they see the value it can add to their businesses. In many instances training and development of staff are the difference between success and failure. 
Despite the increased emphasis on the importance of training and development in small businesses, research into training and development in SMEs has been relatively neglected in the literature. The majority of the research studies that have previously been conducted focused on the importance of managerial training and Strategic Human Resource Management development, mostly focusing on larger organisation (Fuller-Love, 2006:174; Lange, Ottens \& Taylor, 2000:5; Jones, 2004:96). It is largely implied that training and development is a worthy initiative for SMEs and that it will boost SMEs business performance (Loan-Clarke et al., 1999:296). The purpose of this study was therefore to determine the perception of entrepreneurs or SME owners towards the importance of training and development in small businesses.

The literature discussion will start by contextualising training and development where after the importance of training and development in SMEs will be emphasized. The literature discussion will conclude with a discussion on the essential training and development programmes in organisations. The research objectives, methodology and findings will then we explained followed by the recommendations and conclusions to the study.

\section{THE IMPORTANCE OF TRAINING AND DEVELOPMENT}

Training can be defined simply as a systematic approach to learning so as to develop individual, team and organisational effectiveness by means of improving their knowledge, developing skills, and bringing about attitude and behavioural changes, to perform these effectively and efficiently (Aguinis \& Kraiger, 2009:452; Ongori \& Nzonzo, 2011:187). In other words, training refers to a planned effort by an organisation to enable employees to acquire certain job-related competencies, such as knowledge, skills or behaviours that are essential for positive job performance. De Vos and Willemse (2011:27) identified two types of training, namely formal and informal training. Formal training refers to learning that ensues based on a planned structure that is constructed in terms of objectives, time and resources. Informal training, on the other hand, refers to learning stemming from daily activities related to work, family and leisure. Informal training is not structured or organised in terms of objectives, time or learning support (de Vos \& Willemse, 2001:27).

Development, according to Aguinis and Kraiger (2009:452), refers to activities leading to the acquisition of new knowledge and skills for the purpose of personal growth. Training and development is therefore the framework for helping employees to improve their personal and organisational skills, knowledge and abilities (HRM, 2009:1).

\section{Importance of Training and Development In SMEs}

Small organisations, according to Kitching and Blackburn (2002:viii) are less likely to provide their employees with formal training which can be ascribed to a number of reasons. These reasons may be time related or cost related both elements SME's traditionally have limited resources for. While there is evidence that skills and training policies in large organisations have specific benefits, the same would seem to not be true in the case of SME's (OECD, n.d.:3). SME's participation in training activities is up to $50 \%$ less than that of larger organisations and the smaller the size of the business, the wider is the gap in participating in training and development initiatives (OECD: n.d.:3).

Storey (2004:112) identified two main reasons for SMEs not providing training and development initiatives in their businesses. Firstly, it would seem that SME owners generally underestimate the benefits that training can offer to the business, the workforce and managers. Secondly, SME owners generally provide less training and development initiatives to staff as the perception is that the costs are higher and the benefits lower than larger organisations (Storey, 2004:113). The literature further explains that SMEs do not necessarily have sufficient capital available to invest in the skills development of their employees (OECD, 2002:12). It is explained that SMEs may not invest amply in external employee training due to short-termism and failure to accumulate the benefits from the costs of training (European Commission, 2009:24). Another challenge facing SMEs with regard to the implementation and availability of training initiatives is that the trainee may not remain with the business for a prolonged period for the disbursement on training costs to be recouped (OECD, 2002:12). Lastly, Bélanger and Hart's (2012:77) study revealed that the irregular development of learning among SMEs is related to both the size of the business as well as their position towards share productivity and innovativeness. It is these differing costs and benefits that explain why SMEs provide less training and development ascendancies to employees (Storey, 2004:113). Nevertheless, it is 
renowned that the involvement of unskilled employees in SMEs remains a central challenge for the prodigious majority of SMEs (Bélanger \& Hart, 2012:77).

Kotey and Folker (2007:215) state that training is believed to be the most prevailing driver to improve the competencies of employees and to assist towards the growth and increase of profitability of an organisation. Chandler and McEvoy (2000:43) further state that organisations that empower employees through training and development are prone to have less employee turnover, greater productivity and greater financial performance.

It is vital for SMEs to have access to training programmes that educate them and their staff on how they can improve their business and managerial skills and successfully run their companies (IFC, 2011:1). While the majority of businesses concur that training and development should be an integral part of all businesses, the structures that are in place too often do not comply with the specific needs of SMEs (Jolly, 2003:21). There are various important training and development initiatives SMEs should consider to grow and develop their employees as well as their business. Some of these are:

- Basic accountancy training

- Career development initiatives

- Communication, people and social skills

- Computer training

- Customer service training

- Executive/managerial training

- Leadership training

- Literacy/numeracy training

- Marketing your business

- Strategic planning for your business training

- Technical training

These training and development programmes are only a few initiatives that can aid SMEs to ensure that their employees have the most up to date and explicit knowledge available in their respective areas of specialisation (Khandekar \& Sharma, 2005:217).

\section{RESEARCH OBJCTIVES AND METHODOLOGY}

It is stated in the literature that SMEs are not always providing training and development initiatives in their businesses as SME owners generally underestimate the benefits that training can offer to the business as well as the perceived cost-benefit of training. This give rise to the question: What is the current perspective of South African SME owner's on training and development initiatives? The aim of the research is to determine SME owner's perspective on the importance and benefits of training and development initiatives in South Africa SME's.

In order to determine the SME owner's perspective on training and development perspectives a self-administered questionnaire was distributed to a sample of SME owners who registered their businesses at an official state institution for SME's. The questionnaire was consists of quantitative questions allowing small business owners to indicate whether training is provided and whether staff is allowed to attend training courses as well as the business position towards training and development issues. The sampling methodology utilised was that of non-probability, convenience sampling, which enabled the researcher to collect data quickly and easily. Sufficient number of questionnaires was distributed to achieve a confidence level of $95 \%$ and an error margin of $5 \%$ at $50 \%$ response distribution. A total of 150 questionnaires were received of which 60 contained useful responses. The useful responses (60) yield an error margin of $12.54 \%$. The number of responses will only give a general indication of the importance and benefits of training and development initiatives in South Africa SME's.

The quantitative data was analysed using IBM SPSS Statistics V22. The data was checked, coded, corrected and descriptive statistics (frequency counts) were used to describe the findings. An Experience Index (EI) was calculated by subtracting the top 2 bottom responses from the top- 2 top responses in the rating questions. Two-Step Cluster 
analysis was performed in order to identify similar groups of respondents in their attitude towards optimizing the benefits of training in the SME.

\section{RESEARCH FINDINGS}

\subsection{The Sample Characteristics}

The characteristics of the sample in terms of the gender, age group, qualifications, position, years in operation, turnover and SME sector (Table 1).

Almost two-thirds (61.2\%) of the respondents are female. More than half $(57,1 \%)$ of the respondents are from the age group "older than 40 ". The responses to age question are significantly skewed from a normal distribution, with skewness of $-.875(\mathrm{SE}=.340)$ and kurtosis of $-.888(\mathrm{SE}=.668)$. The relative low standard deviation indicates that the responses were very similar with most of the respondents being older than 40 years $(\mathrm{M}=3.88, \mathrm{SD}=1.495)$.

Almost two-thirds (61.4\%) of the respondents to the qualification question have higher than matric qualifications. The responses are not significantly skewed from a normal distribution, with skewness of $.259(\mathrm{SE}=.316)$ and kurtosis of $-.753(\mathrm{SE}=.623)$. The relative high standard deviation indicates that the responses were not similar but spread over mainly three different qualifications categories $(\mathrm{M}=2.98, \mathrm{SD}=1.142)$. Half $(50 \%)$ of the respondents are owners of the SME's included in the study.

More than half $(59,6 \%)$ of the SME's are in business for less than 5 years. The responses are significantly skewed from a normal distribution, with skewness of $1.334(\mathrm{SE}=.316)$ and kurtosis of $-1.064(\mathrm{SE}=.623)$. The relative low standard deviation indicates that the responses were similar with most of the businesses being in operation for less than 5 years $(\mathrm{M}=1.58, \mathrm{SD}=0.823)$.

Table 1. The sample characteristics

\begin{tabular}{|c|c|c|}
\hline Gender & Count(n) & $\%$ \\
\hline Male & 19 & 38.8 \\
\hline Female & 39 & 61.2 \\
\hline Total & 49 & 100 \\
\hline \multicolumn{3}{|l|}{ Age } \\
\hline $18-24$ & 5 & 10.2 \\
\hline $25-29$ & 8 & 16.3 \\
\hline $30-34$ & 3 & 6.1 \\
\hline $35-39$ & 5 & 10.2 \\
\hline$>40$ & 28 & 57.1 \\
\hline Total & 49 & 100 \\
\hline \multicolumn{3}{|l|}{ Qualification } \\
\hline No Matric & 4 & 7 \\
\hline Matric & 18 & 31.6 \\
\hline Certificate/diploma & 17 & 29.8 \\
\hline Degree & 11 & 19.3 \\
\hline Post Degree & 7 & 12.3 \\
\hline Total & 57 & 100 \\
\hline \multicolumn{3}{|l|}{ Position } \\
\hline Owner and manager & 19 & 33.9 \\
\hline Manager & 9 & 16.1 \\
\hline Owner & 28 & 50 \\
\hline Total & 56 & 100 \\
\hline
\end{tabular}

(Table 1 continued on next page) 
(Table 1 continued)

\begin{tabular}{l|c|c}
\hline Years in Operation & & 54 \\
\hline Less than 5 years & 34 & 23.8 \\
\hline $6-10$ & 15 & 9.5 \\
\hline $11-25$ & 6 & 3.5 \\
\hline Over 25 & 2 & $\mathbf{1 0 0}$ \\
\hline Total & $\mathbf{5 7}$ & $\mathbf{\%}$ \\
\hline Turnover & Count(n) & 20.8 \\
\hline$<$ R100 000 & 21 & 15.1 \\
\hline R100 000-200 000 & 11 & 11.3 \\
\hline $200000-500000$ & 8 & 13.2 \\
\hline $500000-1000000$ & 6 & $\mathbf{1 0 0}$ \\
\hline$>$ R1 000 000 & 7 & 22.6 \\
\hline Total & $\mathbf{5 3}$ & 17.7 \\
\hline SME Sectors & & 11.3 \\
\hline Construction & 14 & 8.1 \\
\hline Business services & 11 & 6.5 \\
\hline Retail & 7 & 6.5 \\
\hline Manufacturing & 5 & 4.8 \\
\hline Food /Catering & 4 & 3.2 \\
\hline Bank/Insurance & 4 & 19.3 \\
\hline Transport & 3 & $\mathbf{1 0 0}$ \\
\hline IT & 2 & $\mathbf{2}$ \\
\hline Other & 12 & \\
\hline Total & $\mathbf{2}$ & \\
\hline
\end{tabular}

More than a third $(39,6 \%)$ of the have a turnover of less than R1 000000 . The responses are significantly skewed from a normal distribution, with skewness of $.653(\mathrm{SE}=.327)$ and kurtosis of -.949 $(\mathrm{SE}=.644)$. The relative low standard deviation indicates that the responses were similar with most of the SME's in the study having an annual turnover of less than $\mathrm{R} 100000$ years $(\mathrm{M}=2.38, \mathrm{SD}=1.444)$.

Almost a quarter $(22.6 \%)$ of the SME's are from the construction sector followed by the Business services sector $(17.7 \%)$ and then the Retail sector $(11.3 \%)$. The SME sectors with only one respondent $(1.6 \%)$ were collated in the others and consists sectors beauty, government, cleaning, entertainment, laundry, wholesale, textile, travel, accommodation, health care and network marketing.

\subsection{The Current Stance of Training and Development Initiatives in SME Businesses}

The respondents were asked to indicate whether they received any formal training in the past year as well as the type of training that they had received.

The majority of the respondents $(53.4 \%)$ did receive formal business training during the past year. From multiple response analysis of the type of training which was provided to the respondents or staff members. More than half $(53.8 \%)$ received training in communication, people and social skills whereas a quarter $(25 \%)$ received technical training. (Figure 1). 
Figure 1. Percentage of respondents who received different types of training for themselves or staff members $(\mathrm{N}=52)$

\begin{tabular}{|r|r|}
\hline Communication, people and social skills & $53.80 \%$ \\
Customer service training & $46.20 \%$ \\
Computer training & $46.20 \%$ \\
Leadership training & $44.20 \%$ \\
Strategic planning for your business training & $38.50 \%$ \\
Basic accountancy training & $38.50 \%$ \\
Marketing your business & $32.70 \%$ \\
Career development initiatives & $30.80 \%$ \\
Literacy/numeracy training & $28.80 \%$ \\
Other & $25.00 \%$ \\
Technical training & $25.00 \%$ \\
\hline
\end{tabular}

Most of the respondents do not participate or provide subsidized government training (61.4\%) (Figure 2).

Figure 2. Percentage of respondents who participate or provide subsidized government training $(\mathrm{N}=57)$

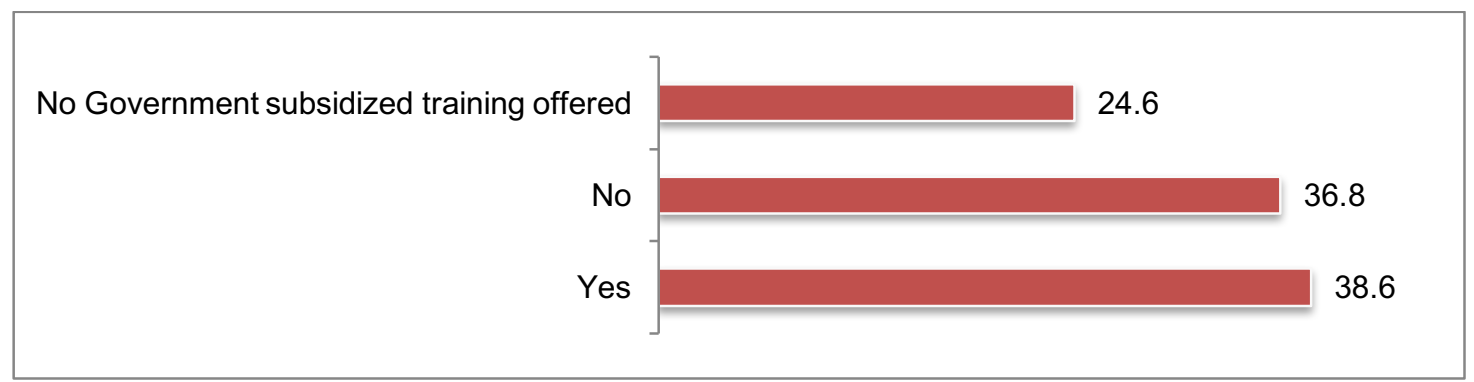

\subsection{The Perception Towards the Importance of Training and Development in SME Organisations}

Respondents were asked to rate the degree to which they agree or disagree with eight statements regarding their attitude towards training and development programmes on a scale of 1-5, 1 being "Strongly disagree" and 5 being "Strongly agree". The responses for "Strongly disagree" and "disagree" was combined into a new category called "strongly disagree \& disagree" (Bottom 2). In the same way the responses for "Agree" and "Strongly agree" was combined into a new category called "Strongly agree \& Agree" (Top 2). (Table 2) 
Table 2. Descriptive Statistics the attitude towards training and development initiatives

\begin{tabular}{|c|c|c|c|c|c|c|c|c|c|}
\hline & \multirow[b]{2}{*}{$\mathbf{N}$} & \multirow[b]{2}{*}{ Minimum } & \multirow[b]{2}{*}{ Maximum } & \multirow[b]{2}{*}{ Mean } & \multirow[b]{2}{*}{$\begin{array}{c}\text { Std. } \\
\text { Deviation }\end{array}$} & \multicolumn{2}{|c|}{ Skewness } & \multicolumn{2}{|c|}{ Kurtosis } \\
\hline & & & & & & Statistic & $\begin{array}{c}\text { Std. } \\
\text { Error }\end{array}$ & Statistic & $\begin{array}{l}\text { Std. } \\
\text { Error }\end{array}$ \\
\hline $\begin{array}{l}\text { I am motivated to learn the } \\
\text { concepts that will be covered } \\
\text { in the training programme }\end{array}$ & 59 & 3 & 5 & 4.51 & .569 & -.617 & .311 & -.618 & .613 \\
\hline $\begin{array}{l}\text { I will try to learn as much as I } \\
\text { can from the training } \\
\text { programme }\end{array}$ & 58 & 4 & 5 & 4.66 & .479 & -.670 & .314 & -1.607 & .618 \\
\hline $\begin{array}{l}\text { I will get more out of the } \\
\text { programme than most people. }\end{array}$ & 58 & 3 & 5 & 4.50 & .600 & -.758 & .314 & -.358 & .618 \\
\hline $\begin{array}{l}\text { I want to improve my } \\
\text { knowledge of the material } \\
\text { that this programme covers }\end{array}$ & 59 & 3 & 5 & 4.59 & .529 & -.749 & .311 & -.684 & .613 \\
\hline $\begin{array}{l}\text { If I can't understand some part } \\
\text { of the programme, I will try } \\
\text { harder }\end{array}$ & 59 & 3 & 5 & 4.54 & .625 & -1.043 & .311 & .082 & .613 \\
\hline $\begin{array}{l}\text { I intend to learn the concepts } \\
\text { that will be emphasized in } \\
\text { this programme }\end{array}$ & 59 & 3 & 5 & 4.56 & .595 & -.998 & .311 & .047 & .613 \\
\hline $\begin{array}{l}\text { I am genuinely interested in } \\
\text { the content of this programme }\end{array}$ & 59 & 3 & 5 & 4.59 & .529 & -.749 & .311 & -.684 & .613 \\
\hline $\begin{array}{l}\text { I am willing to exert } \\
\text { considerable effort to improve } \\
\text { my knowledge by taking this } \\
\text { programme }\end{array}$ & 55 & 3 & 5 & 4.73 & .489 & -1.533 & .322 & 1.448 & .634 \\
\hline
\end{tabular}

It is clear from the descriptive statistics in table 2, that the frequencies for all the items are significantly skewed from a normal distribution and can therefore be regarded as non-normally distributed. The relative low standard deviations indicate that the responses were similar with the mean values all above 4 .

The Experience Index in figure 3 below shows that almost all of the respondents selected the top 2 ratings (strongly agree and agree).Respondents are very positive towards training and development programmes and we can assume that they regard it as a high priority.

Figure 3. Experience index of the attitude toward training and development initiatives

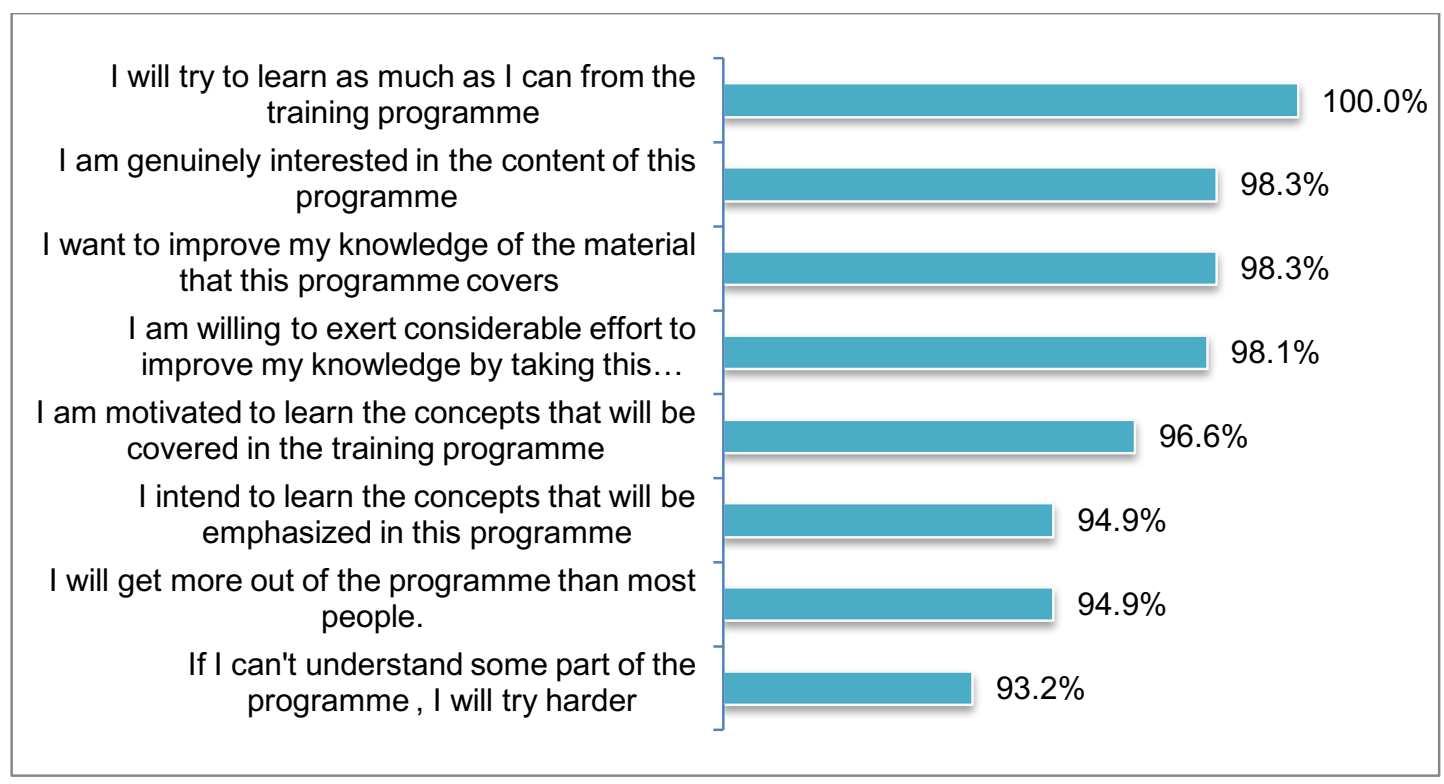


To establish whether the eight statements of the theme "learning intent" are related, an item analysis was performed. An initial overall Cronbach's alpha value of .939 was recorded for the eight statements.

\subsection{The Perceived Importance of Training and Development Initiatives}

Respondents were asked to list the training programmes they would like to attend to improve their skills in the business (Figure 4). From multiple response analysis of the type of training wanted it can be seen that the top three areas are:

- Business Management(32.6\% of respondents)

- Financial Accounting (30.2\% of respondents)

- Marketing (25.6\% of respondents)

Figure 4. Percentage of respondents mentioned that they need different types of training $(\mathrm{N}=40)$

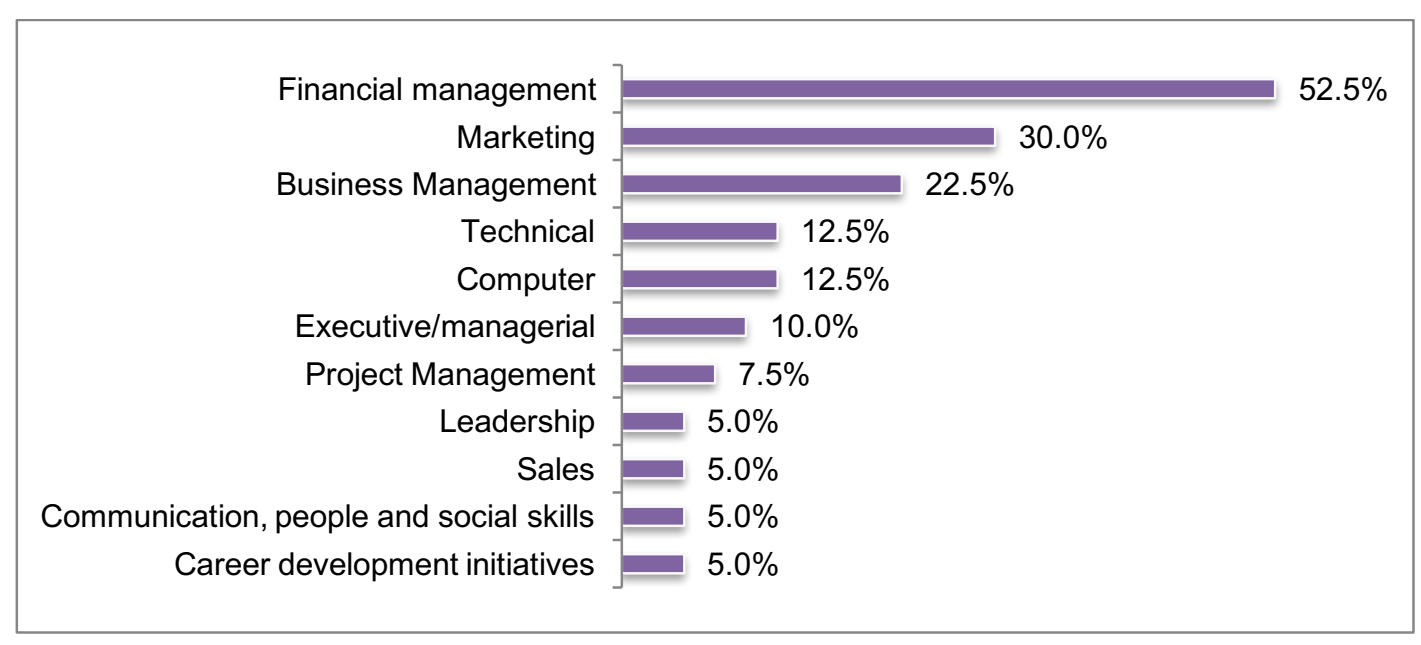

\subsection{The Optimization of the Benefits of Training and Development Initiatives}

The respondents were asked to indicate the extent to which a number of statements that describe the optimization of the benefits of training are true in their SME's on a scale of one to five with higher values corresponding to higher levels of the truth (Figure 5). The lower to levels of the truth was combined as well as the upper two levels. 
Figure 5. Trueness Levels of the optimization of training benefits

\begin{tabular}{|c|c|c|c|}
\hline & \\
Colleagues support the use of learning on the job & $14.0 \%$ & $19.3 \%$ & $66.7 \%$ \\
Supervisors make sure that employees have the \\
opportunity to use their training immediately \\
Employees who use their training are given \\
preference for new assignments
\end{tabular}

The mean rating of each of the statements was calculated (Figure 5). The two highest rated ICT benefits are that it enhances access to market information and knowledge (Mean = 3.41) and facilitates new ways of managing and organising businesses knowledge (Mean = 3.41). All of the mean values are higher than the middle value $(3)$ of the scale (from 1 to 5) used to express the extent to which a respondent rated the trueness of the statements, indicating that most of the respondents agree that all eight statement are sometimes to always true for their business. This is an indication that the SME's in the study are dedicated to optimise the benefits of training in their business by having various practices in place in order to encourage and enforce skills which training was received in. 
Figure 6. Mean levels of the trueness of the optimization of training benefits

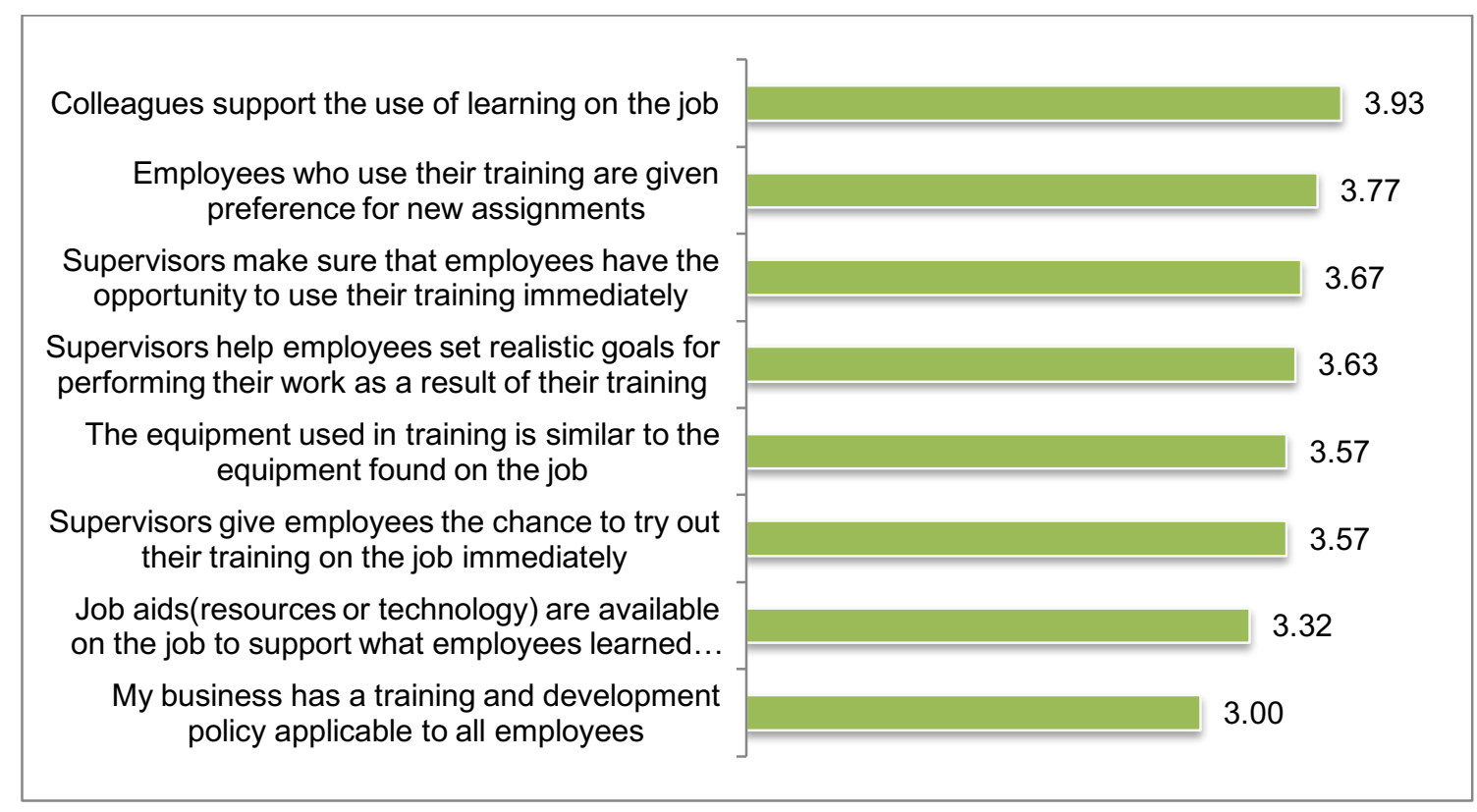

To establish whether the eight statements of the theme "optimisation of training benefits" are related, an item analysis was performed. An initial overall Cronbach's alpha value of .928 was recorded for the eight statements. High correlations (above .422) exist between all the statements of this theme. The eight statements are therefore related to the same theme.

To establish whether there are distinct patterns among the respondents regarding how well they support and optimise the benefits of training, the eight items were subjected to 2-step Cluster analysis.

Three different groups were distinguished, indicating that respondents do have different opinions regarding how true the statements are for their business. The one group consist of 20 respondents, the second group of 17 respondents and the third group of 16 respondents. The cluster centre values of the three groups are depicted in Figure 7.

Respondents belonging to Cluster 1 consider the statements which optimises training benefits as mostly true. The mean rating of the eight factors by respondents in Cluster 1 was 3.80 which are above the average of 3 . Cluster 1 can be described as the "Mostly Agree" group. Respondents in Cluster 2 consider the statements which optimise training benefits as sometimes/rarely true and their average rating was 2.38. Cluster 2 can be described as the "Sometimes/Rarely True" group. Respondents in Cluster 3 consider the statements which optimise training benefits as always true and their average rating was 4.55 . Cluster 3 can be described as the "Always True" group. 
Figure 7. Central Values for the Training Optimization Clusters

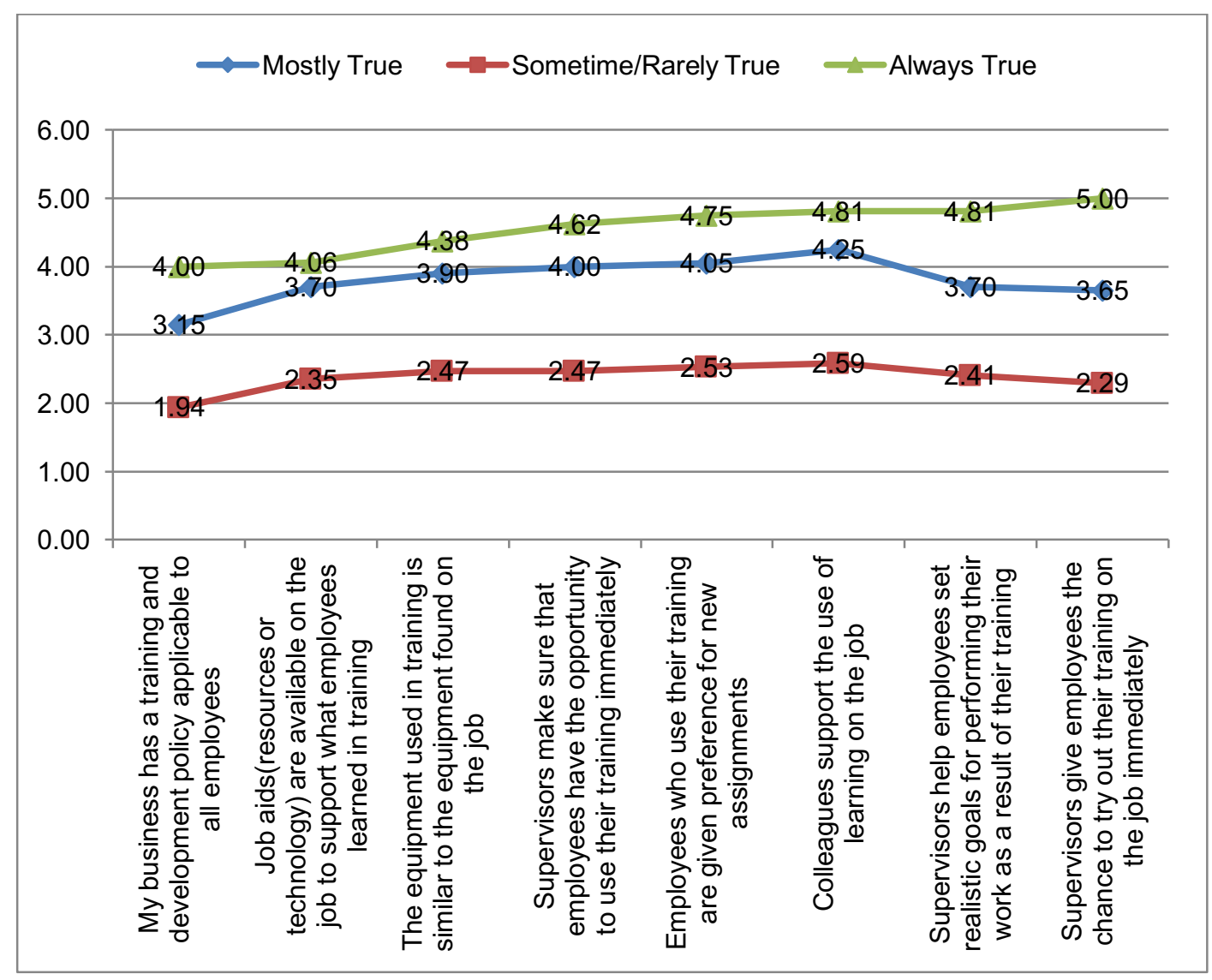

To understand why there is such a difference between the three clusters in their optimizing of training benefits to their SME's, various demographic and other characteristics were investigated.

The Chi-Square Test showed a significant relationships $\left(\chi^{2}(4, \mathrm{~N}=52)=10.952, \mathrm{p}=.027\right)$ between the cluster group and whether the SME provides or participates in any government subsidised training programmes. The "Always True" cluster has $50 \%$ of respondents who provides or participate in government subsidized training while the "mostly true" cluster only has $35 \%$ of respondents who provides or participate in government subsidized training with the "sometimes/rarely true" cluster group having only $25 \%$ of respondents who provides or participate in government subsidized training (Figure 8). Furthermore $68.8 \%$ of the respondents of the "sometimes/rarely true" cluster do not provides or participate in government subsidized training. 
Figure 8. Percentage of Respondents and their participation in government subsidized training programs in each Cluster Group

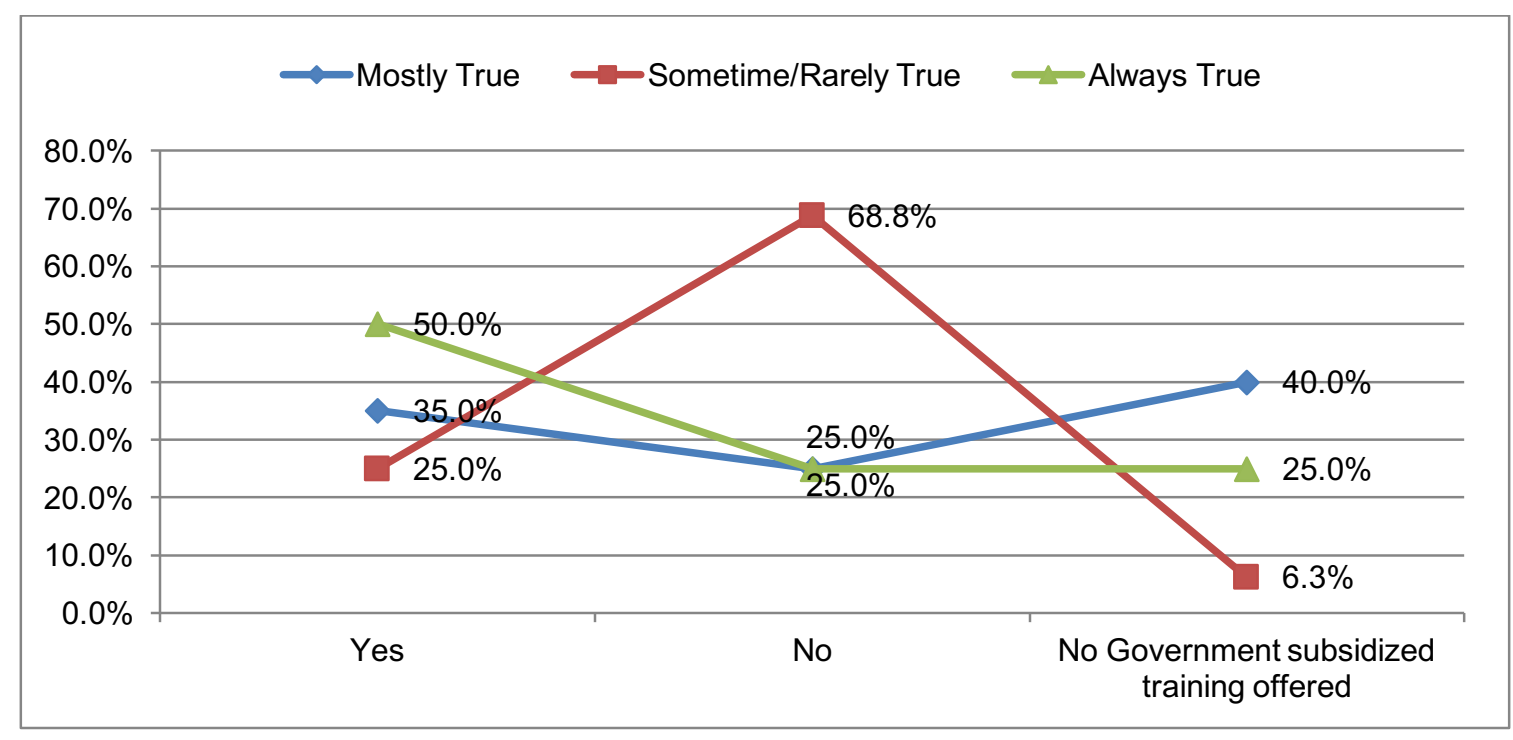

\section{CONCLUSION AND RECOMMENDATIONS}

Training is defined as organized activity aimed at imparting information and/or instruction to improve the recipient's performance or to help him or her attain a required level of knowledge or skill (Business Dictionary n.d). The goal is thus to improve performance; capacity; productivity; and consistency. In a SME improvement in an employee/employer's performance; capacity; productivity and consistency can translate in sustainability, business growth and progress, reduction in supervision and cost, improved quality of services and products, elimination of employee weaknesses and so on. Despite of these benefits, earlier studies indicated that SME owners do not provide training and development initiatives in their businesses.

According to Storey (2004:113) the main reasons for not providing training are that SME owners generally underestimate the benefits that training can offer to the business, the workforce and managers. Secondly, SME owners generally provide less training and development initiatives to staff as the perception is that the costs are higher and the benefits lower than larger organisations (Storey, 2004:113). The aim of the research is to determine SME owner's perspective on the importance and benefits of training and development initiatives in South Africa SME's.

The study revealed that the current stance of training and development initiatives in SME businesses are encouraging with the majority of the respondents receiving formal business training during the past year. The top five areas of training which was provided, being communication, people and social skills, customer service, computer, leadership and strategic planning. It clear from the study that most of the respondents do not participate or provide subsidized government training.

The study further revealed that the majority of the respondents are dedicated to optimise the benefits of training in their business by having various practices in place in order to encourage and enforce skills which training was received in. This is done by colleagues supporting the use of learning on the job, employees who use their training are given preference for new assignments, supervisors make sure that employees have the opportunity to use their training immediately, supervisors help employees set realistic goals for performing their work as a result of their training, the equipment used in training is similar to the equipment found on the job, supervisors give employees the chance to try out their training on the job immediately, job aids (resources or technology) are available on the job to support what employees learned in training and the business has a training and development policy applicable to all employees. The respondents were divided into three distinct groups regarding their attitude towards optimizing of training benefits. A significant relationship was found between the cluster groups and whether the SME provides or 
participates in any government subsidised training programmes. The "Always True" clusters has $50 \%$ of respondents who provides or participates in government subsidized training while the "mostly true" cluster only has $35 \%$ of respondents who provides or participate in government subsidized training with the "sometimes/rarely true" cluster group having only $25 \%$ of respondents who provides or participate in government subsidized training. Furthermore $68.8 \%$ of the respondents of the "sometimes/rarely true" cluster do not provides or participate in government subsidized training. We can conclude that if SME's can be more involved in government subsidized training, they will have a more positive attitude towards supporting training and try to enhance the long term benefit of training to their businesses.

The findings of the study that SME owners are dedicated to optimise the benefits of training in their business by having various practices in place in order to encourage and enforce skills is in contrast earlier studies. Given the small sample size that was used was small $(n=60)$, the results only give a general indication of SME owner's perspective on the importance and benefits of training and development initiatives in South Africa SME's. Therefore, the findings cannot be generalised as being representative of all South African SMEs, further research in this area is therefore recommended. Given the benefits and importance of training in the SME sector, it is recommended that SME owners continue to invest in training and development.

\section{AUTHOR BIOGRAPHIES}

Johannes A. Wiid is a Professor in the Department of Marketing and Retail Management at the University of South Africa (Unisa). He has published numerous articles in refereed journals and is the editor and author of various marketing related textbooks. These books are widely prescribed at universities in South Africa. He holds a DCom in Marketing from the University of Johannesburg.

Michael C. Cant is a Research Professor in the Department of Marketing and Retail Management at the University of South Africa (Unisa). He has published numerous accredited articles in refereed journals and is the editor and author of numerous marketing textbooks. These books are widely prescribed at universities in South Africa. He has presented papers at more than 50 international conferences all over the world and is a well-respected marketing and retail scholar. He holds a DCom in Marketing from the University of South Africa (Unisa).

Claudette Rabie is a lecturer in the Department of Marketing and Retail Management at the University of South Africa (Unisa). She graduated from Unisa with a MCom inBusiness Management with specialisation in Marketing Management and is currently undertaking her PhD degree in Management Studies at Unisa. Her areas of interest include consumer behaviour, merchandising and SME development.

\section{REFERENCES}

Adcorp. (2012). Adcorp Employment Index February 2012 Press Release. [Online] Available from: http://www.adcorp.co.za/ Industry/Documents/12\%2003\%202012\%20REPORT\%20Adcorp\%20Employment\%20Index\%20February\%202012.p df [Downloaded: 2014/04/11].

Aguinis, H. \& Kraiger, K. 2009. Benefits of training and development for individuals and teams, organisations and society. The Annual Review of Psychology, 60:451-474. [Online] Available from: http://www.annualreviews.org/doi/pdf/10.1146/annurev.psych.60.110707.163505 [Accessed: 2014-05-12].

Bélanger, P. \& Hart, S. 2012. Leveraging training and skills development in SMEs: an analysis of two Canadian urban regions Montreal and Winnipeg. [Online] Available from: http://www.oecd-ilibrary.org/industry-and-services/leveragingtraining-and-skills-development-in-smes_5k8x61198524-en?crawler=true [Accessed: 2015-02-20].

Business Directory (n.d). Training. (Online) http://www.businessdictionary.com/definition/training.html [Assessed: 8 July 2015]

Cant, M.C. \& Wiid, J.A. 2013. Establishing the challenges affecting South African SMEs. International Business \& Economics Research Journal, 12(6): 707-716. [Online] Available from: http://www.cluteinstitute.com/ojs/index.php/ IBER/article/viewFile/7869/7928 [Accessed: 2015-02-20].

Chandler, G.N. \& McEvoy, G.M. 2000. Human resource management, TQM and firm performance in small and medium-sized enterprises. Entrepreneurship Theory and Practice, 25(1):43-57. [Online] Available from: http://0-web.b.ebscohost .com.oasis. unisa.ac.za/ehost/pdfviewer/pdfviewer?sid=29671092-9899-4360-a725-4fd94cc3ed9d\%40sessionmgr 198\&vid=4\&hid=105 [Accessed: 2014-04-25].

De Vos, A. \& Willemse, I. 2011. Leveraging training skills development in SMEs: an analysis of east Flanders, Belgium. [Online] Available from: http://www.oecd.org/cfe/leed/49180408.pdf [Downloaded: 2014-04-20]. 
Edinburg Group. 2013. Growing the global economy through SMEs. [Online] Available from: http://www.edinburghgroup.org/media/2776/edinburgh_group_research_-_growing_the_global_economy_through_smes.pdf [Downloaded: 2014-04-07].

European Commission. 2009. Guide for training SMEs. [Online] Available from: file://C:/Users/vniekc/Downloads/ Guide_EN.pdf [Downloaded: 2015-02-20].

Farvaque, N., Voss, E., Lefebvre, M. \& Schütze, K. 2009. Guide for training in SMEs. [Online] Available from: http://www.google.co.za/url?sa=t\&rct=j\&q=\&esrc=s\&source=web\&cd=4\&ved=0CDQQFjAD\&url=http\%3A\%2F\%2F ec.europa.eu\%2Fsocial\%2FBlobServlet\%3FdocId\%3D3074\%26langId\%3Den\&ei=DaRDU6PuBNPQ7AbroYGYCw \&usg=AFQjCNEFDoDPn8MOR9fdmrwSErFtlkzeEA\&bvm=bv.64367178,d.d2k [Accessed: 2014-04-08].

Fuller-Love, N. 2006. Management development in small firms. International Journal of Management Reviews, 8(3):175-190. [Online] Available from: http://onlinelibrary.wiley.com/doi/10.1111/j.1468-2370.2006.00125.x/abstract [Accessed: 2014-04-20].

HRM. 2009. Training and development - introduction. [Online] Available from: http://practicehrm.blogspot.com/2009/10/ introduction-to-training-and.html\#outer-wrapper [Accessed: 2014-04-08].

IFC. 2011. Farmer and SME training: Sustainable business Advisory. [Online] Available from: http://www.ifc.org/wps/wcm/ connect/dfbbea00475672db9ec3bf37b5ac3532/SBA_PC_SMEToolkitLAC_FEB11_EN.pdf?MOD=AJPERES [Accessed: 2014-04-08].

Jolly, A. 2003. Skills and training: directory: a complete sourcebook of best practice and training providers. $4^{\text {th }}$ ed. London: Kogan Page. [Online] Available from: http://books.google.co.za/books?id=RT0YtDdx10kC\&pg=PA21\&dq=training+ and + development + in + SMEs\&hl $=$ en $\&$ sa $=X \&$ ei $=$ iu9EUT8JNDg7QautIDIDg\&ved $=0$ CCwQ6AEwAA\#v $=$ onepage \&q= raining\%20and\%20development\%20in\% 20SMEs\&f=false [Accessed: 2014-04-08].

Jones, J. 2004. Training and development, and business growth: a study of Australian manufacturing small-medium sized enterprises. Asian Pacific Journal of Human Resources, 42(1);96-121. [Online] Available from: http://onlinelibrary.wiley.com/doi/10.1177/1038411104041535/pdf [Accessed: 2014-05-20].

Khan, R.A.G., Khan, F.A. \& Khan, M.A. 2011. Impact of training and development on organizational performance. Global journal of Management and Business Research, 11(7):62-68. [Online] Available from: http://www.google.co.za/url?sa=t\&rct=j\&q=\&esrc=s\&source=web\&cd=10\&ved=0CGYQFjAJ\&url=http $\% 3 \mathrm{~A} \% 2 \mathrm{~F} \% 2$ Fjournalofbusiness.org\%2Findex.php\%2FGJMBR\%2Farticle\%2Fdownload\%2F546\%2F487\&ei=73JCU_KhA6aK7Ab JzIHwCw\&usg=AFQjCNHoT4Ari_sstI6_MhmvxpG5Bqallw [Accessed: 2014-04-07].

Khandekar, A. \& Sharma, A. 2005. Organisational learning in Indian organisations: a strategic HRM perspective. Journal of Small Business and Enterprise Development, 12(2):211-226. [Online] Available from: http://books.google.co.za/books?id=moq5lvLkizAC\&pg=PT5\&dq=impact + of + resources + on + smes \&hl=en\&sa=X\&ei= f_NEU4mUHouM7AbltIE4\&ved=0CC4Q6AEwAA\#v=onepage \&q=impact $\% 20$ of $\% 20$ resources $\% 20$ on $\% 20$ smes $\& \mathrm{f}=\mathrm{fa}$ 1se [Accessed: 2014-04-09].

Kitching, J. \& Blackburn, R. 2000. The nature of training and motivation to train small firms. [Online] Available from: http://dera.ioe.ac.uk/4691/1/RR330.pdf [Downloaded: 2014-04-21].

Kotey, B. \& Folker, C. 2007. Employee training in SMEs: effect of size and firm type - family and nonfamily. Journal of Small Business Management, 45(2): 214-238. [Online] Available from: http://onlinelibrary.wiley.com/doi/10.1111/j.1540627X.2007.00210.x/abstract [Accessed: 2014-06-25].

Kulkarni, P.P. 2013. A literature review on training and development and quality of work life. Journal of Arts, Science \& Commerce, IV(2):136-143. [Online] Available from: http://www.researchersworld.com/vol4/issue2/Paper_20.pdf [Downloaded: 2014-04-07].

Laing, I.F. 2009. The impact of training and development on worker performance and productivity in public sector organisations: a case study of Ghana ports and harbours authority. [Online] Available from: https://www.academia.edu/7616707/THE_IMPACT_OF_TRAINING_AND_DEVELOPMENT_ON_WORKER_PER

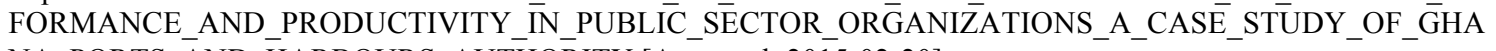
NA_PORTS_AND_HARBOURS_AUTHÖHITY [Accessed: $2015-02-20]$.

Lange, T., Ottens, M. \& Taylor, A. 2000. SMEs and barriers to skills development: a Scottish perspective. Journal of European Industrial Training, 24(1): 5-11. [Online] Available from: http://dx.doi.org/10.1108/03090590010308219 [Accessed: 2014-04-09].

Loan-Clarke, J., Boocock, G., Smith, A. \& Whittaker, J. 1999. Investment in management training and development by small businesses. Employee Relations, 21(3):296-310. [Online] Available from: http://www.emeraldinsight.com/doi/full/10.1108/01425459910273134 [Accessed: 2014-06-26].

OECD. 2002. Management training in SMEs. [Online] Available from: http://www.oecd.org/cfe/smes/2492440.pdf [Downloaded: 2015-02-20].

OECD. Not dated. Innovation in skills development in SMEs. [Online] Available from: http://www.oecd.org/cfe/leed/TSME\%20Highlights\%20FINAL\%20formatted.pdf [Downloaded: 2014-04-08]. 
Ongori, H. \& Nzonzo, J.C. 2011. Training and development practices in an organisation: an intervention to enhance organizational effectiveness. International journal of engineering and management sciences, 24(4):187-198. [Online] Available from: http://www.scienceandnature.org/IJEMS-Vol2\%284\%29-Oct2011/IJEMS_V2\%284\%293.pdf [Downloaded: 2014-04-07].

SBP Alert. 2014. Examining the challenges facing small businesses in South Africa. [Online] Available from: http://smegrowthindex.co.za/wp-content/uploads/2014/11/alert-10.14_print-no-bleed.pdf [Downloaded: 2015-02-20].

Storey, D.J. 2007. Exploring the link, among small firms, between management training and firm performance: a comparison between the UL and other OECD countries. The International Journal of Human Resource Management, 15(1): 112130. [Online] Available from: http://www.tandfonline.com/doi/abs/10.1080/0958519032000157375 [Accessed: 2014 04-20].

The Banking Association of South Africa. Not dated. Small \& Medium Enterprises. [Online] Available from: http://www.banking.org.za/index.php/our-industry/small-medium-enterprise/ [Accessed: 2014-04-07].

UEAPME. Not dated. Learning while working - how skills development in SMEs can be supported. UEAPME background note. [Online] Available from: Http://www.ueapme.com/IMG/pdf/UEAPME_background_note_learning_while_working_ SME_needs_041111.pdf [Downloaded: 2014-04-07]. 
NOTES 